\title{
A Port City in Northeast China: Dengzhou in the
}

\section{Long Eighteenth Century}

RONALD C. PO

\begin{abstract}
If we were asked to recall a coastal city of early modern China, most of us would choose Shanghai, Canton, Xiamen, or Macau. These port cities became famous for facilitating trans-regional sea trade that linked the Qing Empire to the rest of the world. Attentive observers know that all of these cities are located on the Southeast China coast, by which we mean the coastal areas south of Shanghai. Taking Shanghai as the dividing line between the northeastern and southeastern coastlines, the port cities of the south are far more likely to be familiar to us than are those of the north. I consider this phenomenon (i.e. the focus on the coast of early modern China) to be a "Southeast China centrism." And although we might all concede that some southeastern seaports were vital to transoceanic interactions, it is shortsighted to ignore the northern port cities and the role they played in connecting China with the maritime world. In this article I investigate the importance of Northeast China's port cities by focusing particular attention on the less familiar coastal seaport of Dengzhou. By detailing and examining the political and economic importance of this port city in the early modern period, I will show that Qing China's northeastern coast was no less important than the southeast. Even if China's northern port cities might not have been as economically vibrant as those in the south, we should not overlook their functions and histories. Indeed, they also attained unique patterns of political and economic development throughout the long eighteenth century.
\end{abstract}

\section{Introduction}

"Zaiton... the port for all the ships that arrive from India laden with costly wares and precious stones ... It is also the port for all the merchants of all the surrounding territory. And I can assure you that for one spice ship that goes to Alexandria to pick up pepper for export to Christendom, Zaiton is visited by a hundred."1

- Excerpt from Marco Polo, "Description on Zaiton (Quanzhou)," in his Description of the World (1292)

${ }^{1}$ R. Latham, The Travels of Marco Polo (Harmondsworth, I958), p. 237. 
Although Marco Polo's trip to China may be subject to dispute, ${ }^{2}$ he produced what has arguably become one of the most significant accounts of global travel in world history. After all, he brought Chinese civilisation to the attention of the West, and his lively rendering of Quanzhou harbour (Zaiton) became an influential depiction of a Chinese port city for Europeans. ${ }^{3}$ His travelogue succeeded in introducing Europe to an important port city in China at that time, but excluded important coastal areas outside of Southeast China. By "Southeast China", I refer to the coastal region located south of Shanghai. In fact, since the Song dynasty (960-I279), port cities in southeast China became famous as significant links in trans-regional sea trade between China and the wider world. ${ }^{4}$ Taking Shanghai as the midpoint between north and south, we are likely to be far more familiar with port cities to its south than those to its north. From the time when Marco Polo published his account to the time when the five treaty ports were opened to the British, the southeast seacoast was regarded as the gateway to China from the Far West (taixi). As a consequence, in discussions of coastal cities in early modern China, academic attention has long focused on port cities such as Shanghai, Amoy, Fuzhou, and Canton, where European, Islam, and Middle-east traders and travellers had direct cultural and economic interaction and experience. I consider this phenomenon (i.e. the focus on the coast of late imperial China) a "Southeast China centrism." We have been ceaselessly swayed by this centrism from the I950s and, since then, have intensively studied the coast of southeast China, to the exclusion of the northeast. ${ }^{5}$ There are many exciting topics related to the southeastern coast which, no

\footnotetext{
${ }^{2}$ See discussions in Frances Wood, Did Marco Polo go to China? (Boulder, I996) and Hans Ulrich Vogel, Marco Polo was in China: New Evidence from Currencies, Salts and Revenues (Leiden, 2013).

${ }^{3}$ Wang Gungwu, The Nanhai Trade: The Early History of Chinese Trade in the South China Sea (Singapore, 1998): John Chaffee, "At the Intersection of Empire and World Trade: The Chinese Port City of Quanzhou (Zaitun), Eleventh-Fifteenth Centuries," in Kenneth R. Hall (ed.), Secondary Cities and Urban Networking in the Indian Ocean Realm, c. 1400-1800 (Plymouth, 2008), pp. 99-I22; Cho-yun Hsu: Timothy D. Baker and Michael S. Duke (trans.), China: A New Cultural History (New York, 2006), pp. 278-279; John Guy, "Tamil Merchant Guilds and the Quanzhou Trade," in Angela Schottenhammer (ed.), The Emporium of the World: Maritime Quanzhou, 1000-1400 (Leiden, 2000), p. 295; Edward A. Alpers, The Indian Ocean in World History (Oxford, 2014), p. 63 .

${ }^{4}$ See, for instance, Kenneth R. Hall, "Local and International Trade and Traders in the Straits of Melaka Region: 600-I500", Journal of the Economic and Social History of the Orient, Vol. 47, no. 2 (2004), pp. 213-260; Anthony Reid, "An Age of Commerce in Southeast Asian History," Modern Asian Studies, Vol. 24, no. I (Feb, 1990), pp. I-30; Paul van Dyke, The Canton Trade: Life and Enterprise on the China Coast, 1700-1845 (Hong Kong, 2005), pp. I-4; Ralph Kauz (ed.), Aspects of the Maritime Silk Road: From the Persian Gulf to the East China Sea (Wiesbaden, 20I0).

${ }^{5}$ The maritime frontier of Northern China has not been examined comprehensively in the West. For example, Jane Kate Leonard published an interesting article concerning the Qing strategic vision of the maritime space on the northeast coast of China from a "sea transport perspective (haiyun)", but it is only a paper consists I4 pages. See Jane Kate Leonard, “The Qing Strategic Highway on the Northeast Coast”, in Angela Schottenhammer and Roderich Ptak (eds.), The Perception of Maritime Space in Traditional Chinese Sources (Wiesbaden, 2006), pp. 27-4I. Christopher Agnew wrote a fascinating piece, which focuses on Dengzhou and the Bohai Sea from a "regional integration perspective", but it only touches upon the period covering a few decades in the late Ming. See Christopher Agnew, "Dengzhou and the Bohai Gulf in Seventeenth Century Northeast Asia," in Kenneth R. Hall (ed.), The Growth of Non-Western Cities: Primary and Secondary Urban Networking, c. 900-19oo (Lanham, 20II), pp. I7I-I95. Even though the maritime frontier of north Asia were the subject of the First International Seminar on Commissioner Chang Pogo and Ancient Tang-Sila-Japan Maritime Relations (conference held in Wando, Republic of Korea, November, I992), most of the papers have not yet been published. After all, other than Tianjin and Port Arthur, most of the Anglophone readers are not very familiar with the functions and histories of port cities in Northern China. Compared to the southern coast, the northern coast is a subject awaits further studies.
} 
doubt, deserve our attention; however this makes the northeastern coast seem far removed from sea trade and coastal management in the history of Asian port cities. ${ }^{6}$ For instance, in the fantastic volume edited by Frank Broeze entitled Gateways of Asia: Port Cities of Asia in the $13^{\text {th }}-20^{\text {th }}$ Centuries, ports along the Northeast China coast, surprisingly were nowhere to be found in the entire volume. ${ }^{7}$ Although we might all concede that some southeastern seaports were vital to transoceanic interactions, to ignore northern port cities in connection with China and the maritime world in the early modern period is shortsighted. This article aims at breaking through the "Southeast China-centric" framework by focusing attention on a less familiar coastal seaport, Dengzhou. By detailing and examining the political and economic importance of this port city throughout the eighteenth century, I argue that the sea surrounding northeastern China was no less important than that in southeastern China. Even if port cities in the north might not have been as economically vibrant as those in the south, we should not overlook their functions and histories. This paper will show that northeastern cities like Dengzhou also attained unique patterns of development within the political and economic spectrums throughout the long eighteenth century.

I have chosen the long eighteenth century as the timeframe because it has long been misconstrued as a time when China had very little to do with the ocean. Other than the annexation of Taiwan in the r680s and perhaps the sea blockade policy, maritime militarisation and shipping management were rather inconspicuous features of the Qing Dynasty (I644-I9I2) before the arrival of western gunboats in the mid-nineteenth century. Fortunately, this perception is gradually being challenged by a number of prominent scholars in the field of maritime history as the Qing initiated a set of regulations dedicated to maritime trade. ${ }^{8}$ However, the impact of their research is, as yet, insufficient. In line with this promising research, I hope that the present work can serve as an example to show that the Qing was not simply a land-based empire in the eighteenth century, but a sea power concerned with its maritime frontier as well as the development of a number of important coastal cities in the north and south.

\section{The Five Zones}

Perhaps it was the publication of John King Fairbank's influential book, Trade and Diplomacy on the China Coast: The Opening of the Treaty Ports, 1842-1854 in 1953, that fuelled the rise in scholarship on the urban developments and trading patterns of a number of coastal cities in China, especially among historians in the West. The cities that caught attention were primarily the five treaty ports that were forced open as a concession following China's defeat in the First Opium War (I839-I942). In these five ports (Canton, Amoy, Fuzhou, Ningbo, and Shanghai), free trade was enforced between foreigners and Chinese merchants. The infamous treaty port system, symbolising the unique diplomatic relationship between

\footnotetext{
${ }^{6}$ In 2007, Liu Fengming also raised this concern in his Shandong bandao yu dongfang haishang sichou zhi lu (Beijing, 2007), p. 6.

${ }^{7}$ Frank Broeze (ed.), Gateways of Asia: Port Cities of Asia in the 13th-2oth Centuries (London, I997).

${ }^{8}$ See, for instance, Zheng Yangwen, China on the Sea: How the Maritime World Shaped Modern China (Leiden, 20I2); Gang Zhao, The Qing Opening to the Ocean: China Maritime Policies, 1684-1757 (Honolulu, 20I4); and Wang Wensheng, White Lotus Rebels and South China Pirates: Crisis and Reform in the Qing Empire (Cambridge, MA., 20I4).
} 
China and the West, is the origin of the opening of these port cities. The five port cities experienced dramatic growth in economic development under the treaty port system. ${ }^{9}$ Canton, for example, quickly transformed into the economic center in both the Euro-Asian and Asian-Pacific markets; it was even considered the "wonder of the Far East", ${ }^{10}$ where international interactions actually took place in pre-modern times. ${ }^{11}$ The other four treaty ports also went through remarkable development featuring transcultural interaction. Because of this distinctive feature, historians have tended to study the urban development of these coastal cities. Scholars like Linda Cooke Johnson, Rhoads Murphey, and Robert Nield, to name a few, have written beautiful histories of these places. ${ }^{12}$ Their research has not only shed light on the histories of the cities themselves but has enlightened numerous subsequent studies of these sea ports. As many scholars have argued, the coast of Southeast China assuredly had a dynamism that helps us better understand the history of late imperial China as well as early modern global history. ${ }^{13}$

The coast of Southeast China is no doubt worth studying; but, as I have argued, this is a more or less Southeast China-centric way to conceptualise China's coast. This framework may be useful in opening the window to various kinds of economic and cultural exchanges between different peoples, but it keeps us from getting a comprehensive picture of the East Asian maritime world, because significant bodies of water attached to China, such as the Bohai and the Yellow Seas, somehow elude discussion. I think it is about time to shift our attention from south to north in order to generate a better picture of China's coast during the eighteenth century.

By early 1977, the American historical anthropologist William G. Skinner (I925-2008) had already divided China into nine macro-regions according to the drainage basins of the major rivers and other geomorphological features that constrained travel. ${ }^{14}$ Five of these nine regions were linked to the ocean, while two macro-regions, Manchuria and North China, were linked to the northeastern coast (see Figure I). That Skinner's model is compelling is demonstrated by its success in having broadly stimulated area studies over the past few decades. But I do not apply his model in this paper, simply because it is very land-based. Instead, I propose dividing the seas along the coast of China into five discrete, yet interlinked, maritime zones: (I) The Bohai zone, (2) the Jiangsu sea zone, (3) the Zhejiang sea zone,

\footnotetext{
${ }^{9}$ However, as reminded by Gang Zhao, it has to be pointed out that some treaty ports had functioned as commercial and economic centres for more than I 50 years before the arrival of western battleships. It is thus debatable to simply argue that the post-I 840 imperialism of western seagoing merchants are the only actors that catalyzed the rise of the treaty ports as significant commercial centres in East Asia. See Gang Zhao, The Qing Opening to the Ocean, p. I36.

${ }^{10}$ Valery M. Garrrett labels Canton as the "wonder of the Far East" in her Heaven is High, the Emperor Far Away: Merchants and Mandarins in Old Canton (Oxford, 2002).

${ }^{11}$ David Igler, The Great Ocean: Pacific Worlds from Captain Cook to the Gold Rush (Oxford, 20I3), pp. 30-33.

${ }^{12}$ Linda Cooke Johnson, Shanghai: From Market Town to Treaty Port, 1074-1858 (Stanford, I995); Rhoads Murphey, “The Treaty Ports and China's Modernization," in Mark Elvin and William G. Skinner (eds.), The Chinese City between Two Worlds (Stanford, I974), pp. I7-72; and Robert Nield, The China Coast: Trade and the First Treaty Ports (Hong Kong, 2010), pp. 92-25I.

${ }^{13}$ See Jürgen Osterhammel, The Transformation of the World: A Global History of the Nineteenth Century (Princeton, 2009), p. 57; Craig Lockard, Societies, Networks, and Transitions: A Global History (Stanford, 2008), p. 632; Takeshi Hamashita, "Editor's Introduction," in his China, East Asia and the Global Economy: Regional and Historical Perspectives (Abingdon, Routledge, 2008), pp. I-I I.

${ }^{14}$ William G. Skinner, "Regional Urbanization in Nineteenth Century," in The City in Late Imperial China (Stanford, I977), pp. 2I2-2I5.
} 


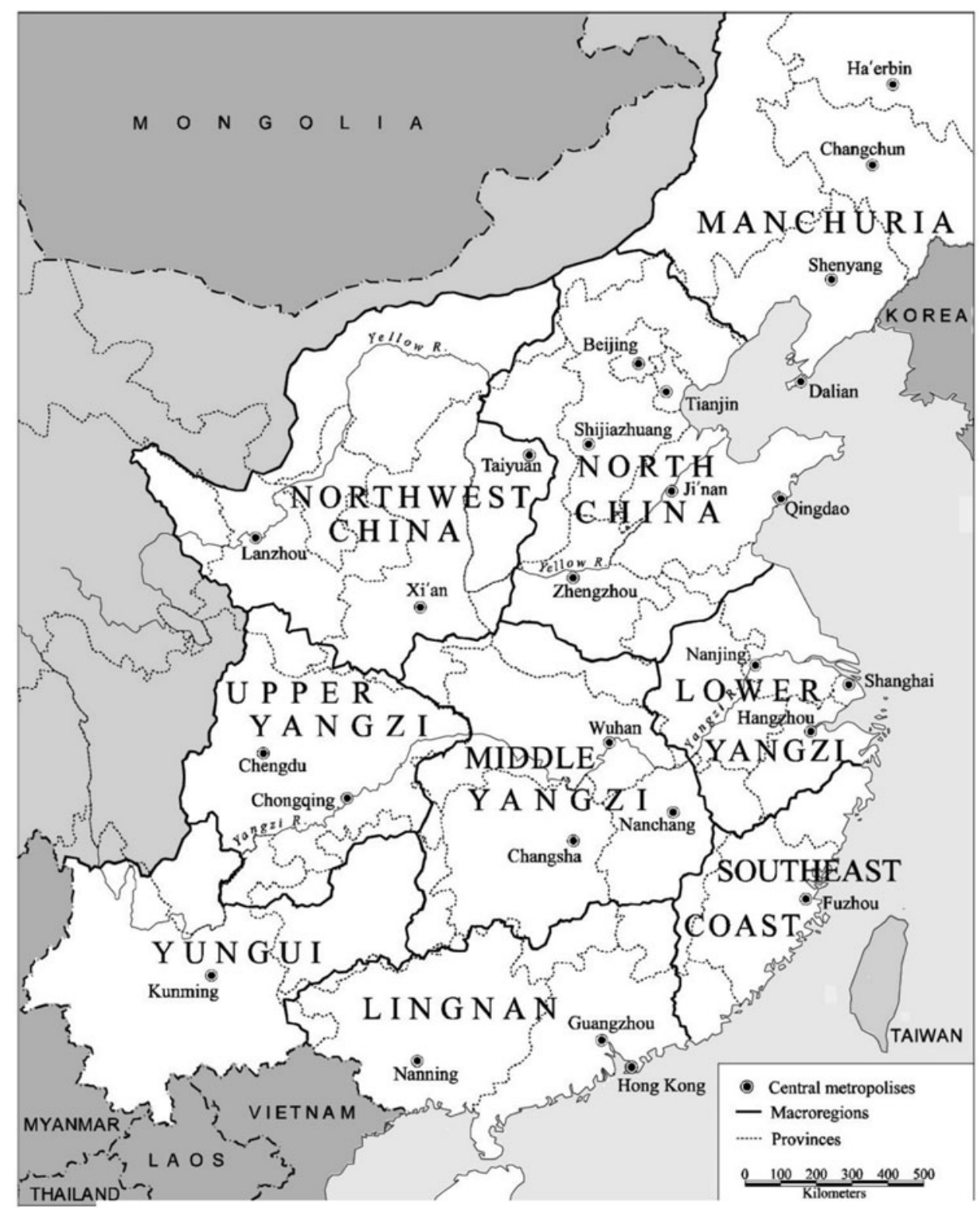

Figure I. The Skinner Model

(4) the Taiwan Strait, and (5) the Guangdong sea zone. This five-zone model derives from a coastal map (haitu) entitled Qisheng yanhai tu (The Coastal Map of Seven Coastal Provinces) officially produced in the late eighteenth century and reprinted subsequently in the nineteenth century. The nineteenth century edition of this coastal map introduces "dividing lines (fenjie)" between specific maritime spaces (see Figure 2). These dividing lines indicate that specific maritime spaces were policed and governed by their respective 


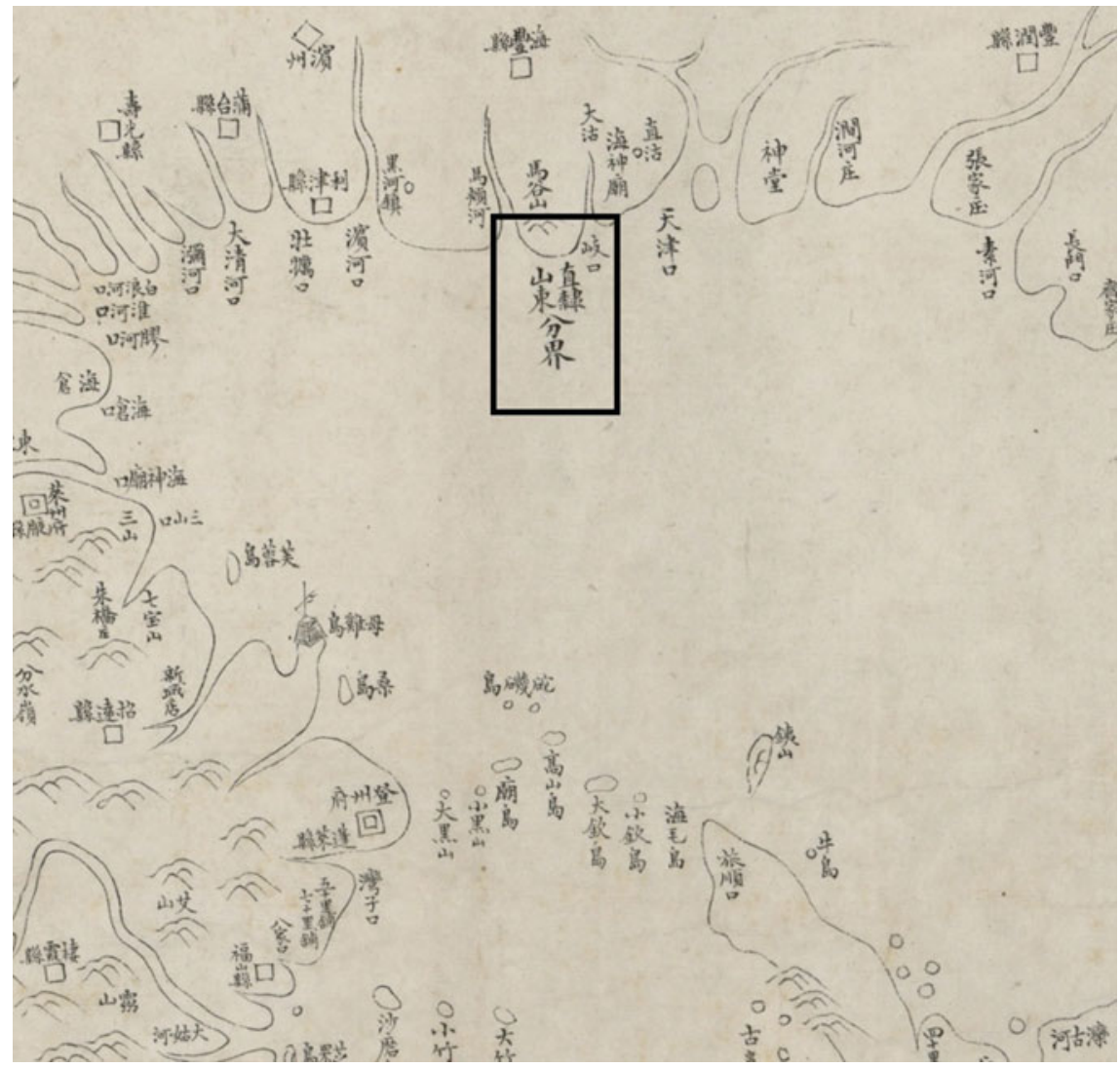

Figure 2. (Colour online) Example of "dividing lines (fenjie)"

(Map: Qisheng yanhai $t u ; 19^{\text {th }}$ century edition)

coastal provinces. Breaking down the maritime frontier of the Qing Empire into the same divisions that were used at that time is perhaps the best way to study the maritime policies, consciousness, and ideologies in question. Understanding the development of coastal China in the late imperial period may also help us escape the Euro-centric framework.

Using the five-zone model, the Bohai zone is of particular concern not only in helping us shift our academic focus "from south to north", but because the Qing court valued it in a deliberate manner throughout the eighteenth century. As the only maritime space connecting three coastal provinces with very different customs and cultures, the Bohai Sea was the maritime gateway leading to the capital region (jingji) and the homeland of the Manchu ruling elite. It was also the maritime space that connected the Chinese capital to Korea, the nearest neighboring state. Transcultural interactions between Chinese, Korean, and Japanese merchants, intellectuals, and even pirates across the Bohai zone were no less dynamic and vibrant than those in the southeastern maritime region. The Bohai zone was also notable for its extensive maritime resources. As Jiang Chenying notes in his Haifang zonglun (A comprehensive study on maritime defense), the Bohai Sea was famous for sea-salt production 
and a variety of fishery products from the Ming onwards. ${ }^{15}$ In his Dushi fangyu jiyao (Essence of historical geography), Gu Zuyu also noted the bountiful sea-salt and seafood production across the Bohai Sea, explaining how it contributed significantly to the prosperous coastal economy along northeast China. ${ }^{16}$ In fact, beginning in the eighteenth century, significant maritime resources (e.g. sea salt) as well as some trading goods produced in northeast China (e.g. soybean paste) were shipped to other parts of China from the Bohai region. ${ }^{17}$ The Bohai zone was therefore considered to be both a strategic corridor to the open sea and a natural buffer for the region surrounding the Qing capital.

The two best known port cities in the Bohai zone are arguably Tianjin and Port Arthur probably because, once again, they were forcefully opened by western imperialistic powers for free trade in the late nineteenth century. Instead of these two port cities, I choose to study Dengzhou, a relatively small and less familiar seaport located in the northern part of Shandong. Despite its size, this port city remained politically and economically important for some time in the eighteenth century. In the pre-modern era, Dengzhou experienced ups and downs in its development, like other coastal cities (not just in China, but all over the world). Once an economically active harbour thronged with traders from all over northeast Asia, it was a fortified naval base established by the Qing court in the early eighteenth century. But it was overshadowed by other coastal cities in later years. Then, in the late nineteenth century, it gained importance once again for a variety of reasons. In order to better comprehend these political and economic changes, we will travel back to late imperial Dengzhou in the sections that follow. In the first section we will briefly introduce the city's geographical location and its history prior to the Qing dynasty. Then we will examine the maritime militarisation of Dengzhou and the Bohai area. In the final section, we will inquire into the city's maritime commerce and its economic significance within the Northeast Asian network Figure 3.

\section{The City}

To southern Chinese and especially to foreigners, Dengzhou may be less familiar than Suzhou, Fuzhou, or Guangzhou, the famed centres of Jiangnan and Guangdong cultures, which feature on so many tourist routes. But to people in northeastern China and especially the natives in Shandong, Dengzhou carries rich historical associations. The Northern Song historian Ye Shi described Dengzhou as a strategic harbour connecting the world beyond the Song Empire. As he noted, "the city is surrounded on three sides by the sea. During the reign [of northern Song], the assorted maritime states that presented tribute to the Emperor in Beijing all came through Denglai”. ${ }^{18}$ The Qing literati Gu Zuyu also valued

${ }^{15}$ Jiang Chenying, Haifang zonglun (Beijing, 20I I), sb.

${ }^{16}$ Gu Zuyu, Dushi fangyu jiyao (Beijing: Zhonghua shuju, 2005), juan 24, 7a.

${ }^{17}$ See Liu Sufen, "Qingzhao zhongye beiyang de haiyun,” in Wu Jiangxiong (ed.), Zhongguo haiyang fazhan lunwenji, Vol. 4, (Taipei, I99I), pp. IоI-I24. Chen Lihua even argued that Dengzhou already established its close connection with Fujian in the Tang Song transition in terms of trade and commerce. See her "Tang Song zhiji Dengzhou gang de fanrong yu Fujian haishang jiaotong de fazhan," Journal of Teacher College (Qingdao University), Vol. 25 no. 2 (June, 2008), pp. $38-43$.

${ }^{18}$ On the discussion of strategic importance of some port cities in Shandong, see Liu Fengming, Shandong bandao yu dongfang haishang sichou zhi lu (Beijing, 2007), p. 203. 


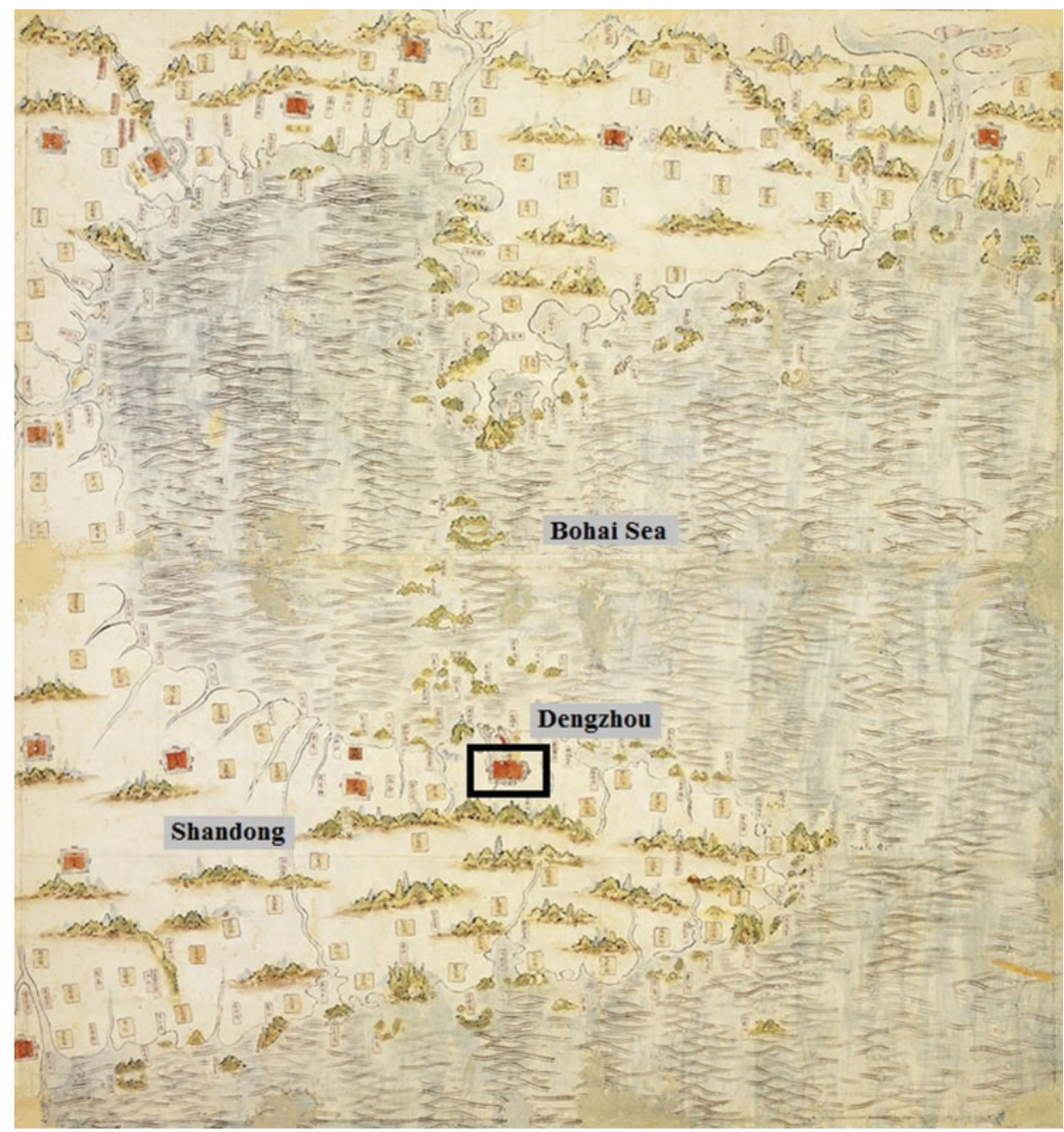

Figure 3. (Colour online) Deng Jin Shan Ning sizhen haitu (Ming edition; National Palace Museum)

Dengzhou as the place that "controls the safety across the Bohai Gulf as well as the Yellow Sea region". ${ }^{19}$

Known as Penglai today, Dengzhou is a coastal city situated in the northern Shandong Peninsula. Its description in the gazetteer Dengzhou fuzhi, as well as evidence in modern atlases, gives us a reasonably good sense of the general topography of the area. The city lies more than a hundred miles from the nearest coastal city, Yantai, and almost five hundred miles from Weihaiwei. Off the northern coast of Dengzhou lies the Miaodao archipelago, or the Long island, which comprises 32 small islands famous for their stunning scenery. In the

${ }^{19} \mathrm{Gu}$ Zuyu, Dushi fangyu jiyao, juan 24, 7a. 
eighteenth century, it was said to take less than a day to reach the Liaodong Peninsula from Dengzhou through the Miaodao archipelago Figures 4 and 5. Dengzhou was also located close to Korean terrain. As recorded in the Official History of the Sui Dynasty, Dengzhou was the point of departure for the Emperor Yang of the Sui's naval attack on Korea. The land to the south and southwest of Dengzhou is flat; but farming is difficult. The nearest inland commercial centre is Laizhou, a traditional city that benefited considerably from its abundant natural resources, such as gold, magnetite, and granite. In the Ming and Qing, Laizhou was closely linked to Dengzhou and Fushan in the east and Qingzhou in the west, within the Shandong transport and postal system. Troops and cavalries could effectively be mobilised from the west (Qingzhou) to the east (Dengzhou and other coastal cities). Although Dengzhou, as such, was only a harbour with limited natural resources and relatively small population (diji minpin), ${ }^{20}$ it had good east-west land and water communications, because it was closely connected to other big urban cities.

Some archeologists have argued that the Shandong peninsula was first settled in the remote past ${ }^{21}$ but the picture of Dengzhou in ancient times is still fragmentary and far less clear than one would wish. We are certain that, from the Tang period onwards, geo-political factors became critical determinants of the historical development of this small coastal city. ${ }^{22}$ Located at the tip of the northern Shandong peninsula, the port was ideally situated for trade with the ports of Liaodong in the north, such as Lushun and Jinzhou. Embraced by the Bohai Gulf and naturally protected by the Miaodao archipelago, it became a desirable naval base from which to extend military control over the Bohai region. Enjoying these geopolitical advantages, Dengzhou served as one of the designated sea ports of entry for foreign tribute and trade missions in the Sui and Tang dynasties. Throughout the Tang era, it was a point of access for foreign dignitaries and traders (mostly Japanese and Korean) to enter the Chinese empire. ${ }^{23}$ This continued to be the case into Song times. As recorded in the Korean archive, the Annals of the Joseon Dynasty, several officials from the Korean state of Silla were allowed to hold military and administrative posts in Dengzhou in order to protect their traders and citizens. ${ }^{24}$ This record suggests that Dengzhou served as a significant station that connected China and Korea politically and economically. Later in the Iozos, however, Dengzhou gradually lost its significance in foreign sea trade. The Northern Song government banned foreign vessels from landing in Dengzhou out of fear that the Korean merchants would support the expansive Liao state in the north by shipping weapons and other supplies through the city. ${ }^{25}$ Since the enforcement of a trade ban required a strong

\footnotetext{
${ }^{20}$ Fang Ruyi, Jia Hu, et. al., Guangxu zeng xiu Dengzhou fuzhi (Nanjing, 2004), p. 73.

${ }^{21}$ For instance, see Richard Pearson and Anne Underhill, "The Chinese Neolithic: Recent Trends in Research", American Anthropologist: Vol. 89, no. 4 (Dec., I987), pp. 807-822; Li Liu, "State Emergence in Early China," Annual Review of Anthropology, Vol. 38 (2009), pp. 2 I 7-232; see also the website "Weihai: City History, Ancient Relics, Archaeological Tours" (http://www.weihai-hotels.com/en/history.html).

${ }^{22}$ See Wang Saishi, Shandong yanhai kaifa shi (Jinan, 2005), pp. I 36-I43; Fan Wenli, “Tangdai Dengzhou haixing ru Gaoli dao de bianqian yu Chishan fahuayuan de xingcheng”, Zhongguo lishi dili luncong, Vol. 20, no. 5 (2005), pp. II4-I25.

${ }^{23}$ Edwin O. Reischauer, "Notes on Tang Dynasty Sea Routes," Harvard Journal of Asiatic Studies, Vol. 5 no. 2 (June, I940), pp. I42-I64.

${ }^{24}$ Liu Fengming, Shandong bandao yu dongfang haishang sichou zhi lu, pp. 23 I-247.

${ }^{25}$ Zhang Zhaodong, Song Yuan Shandong quyi jingji yanjiu (Jinan, 2006), pp. 175-180.
} 


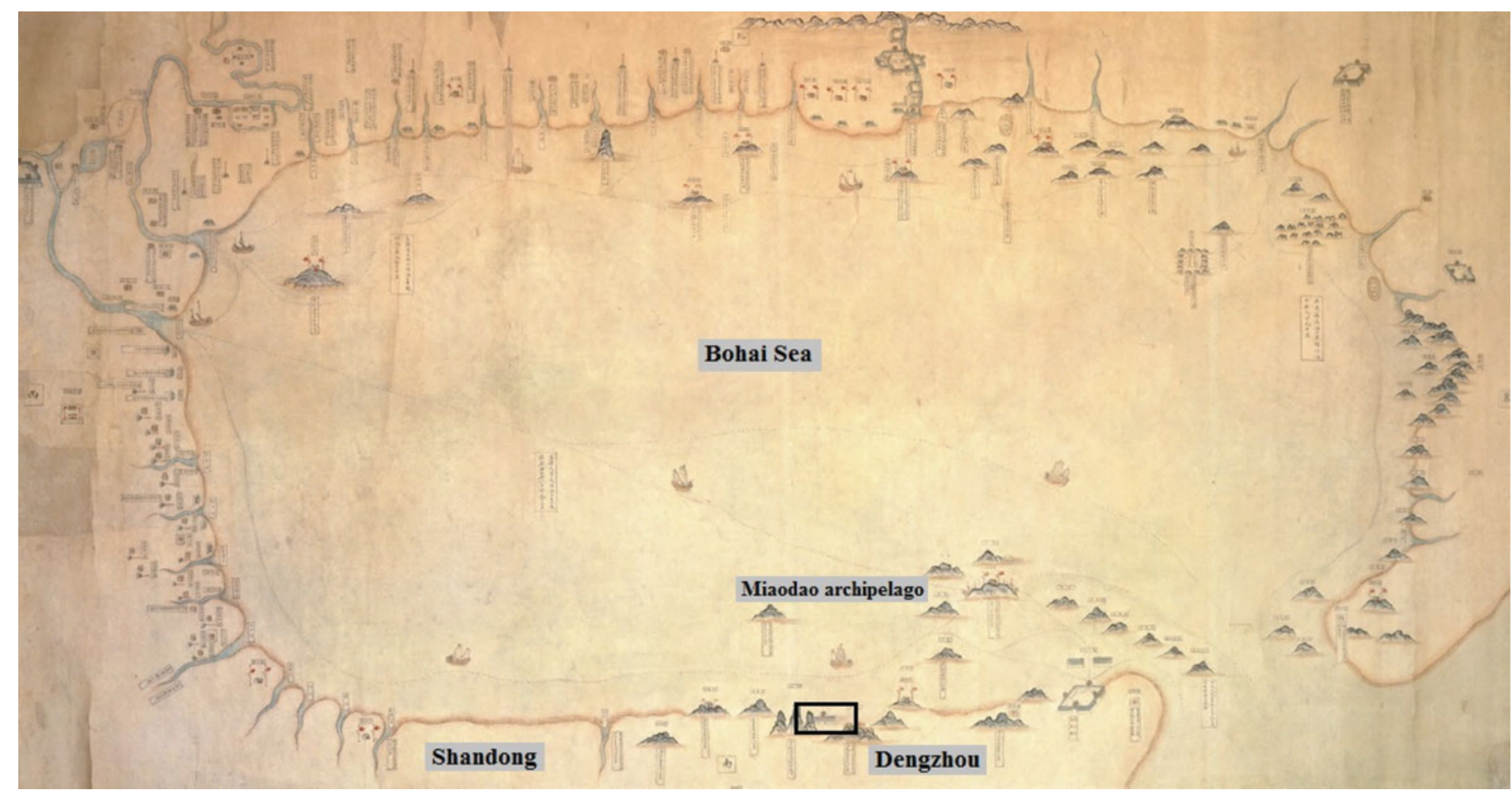

Figure 4. (Colour online) Bohai yanan daoli tu (ca. I 8th century edition; National Palace Museum) 


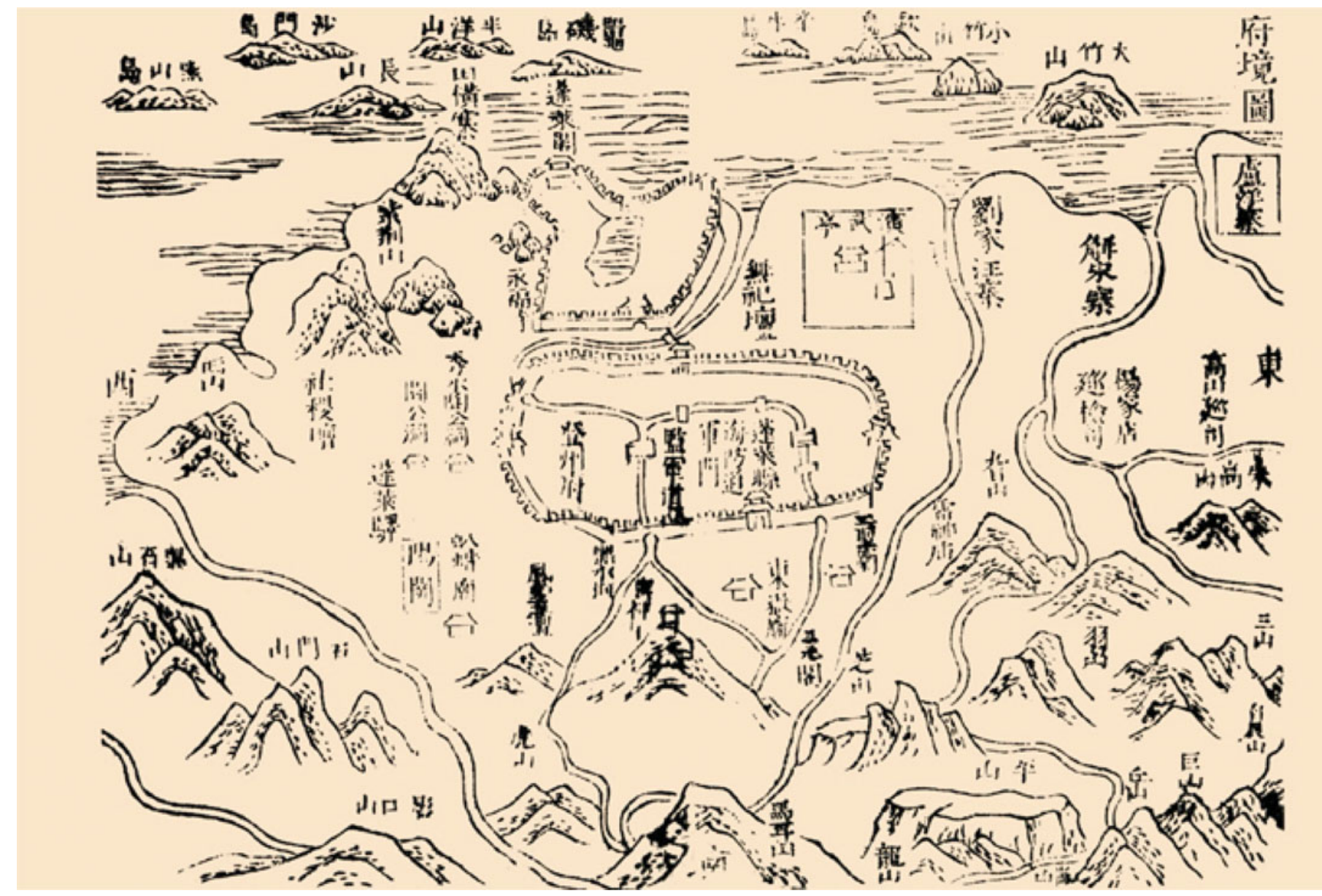

Figure 5. (Colour online) Dengzhou fujing tu (Shunzhi edition) 
military commitment, Dengzhou was quickly transformed from a trading port to a military settlement guarded by roughly three to four thousands soldiers. ${ }^{26}$

During the Yuan dynasty, Dengzhou regained its importance in foreign sea trade. Its geographical location remained a magnet for overseas traders interested in the North China market. Apart from fostering foreign sea trade between China, Korea, and Japan, Dengzhou served as a port for the transportation of grain boats from South China. Its location on the north-south coastal route made it the equivalent of Zhejiang and Suzhou for North China in the thirteenth century. Although the exact quantity of goods imported from the south, mainly from the Jiangnan area, is uncertain, a Yuan dynasty poet described the bustling harbour near Dengzhou as "flooded by porcelain and pots from Jiangsu and cloth from Zhejiang". ${ }^{27}$ For more than two centuries Dengzhou, on the one hand, maintained itself as the principle sea port where travellers and traders gathered to ship and unload their cargoes, on the other, it served as the northern terminus of the grain boats network along the coast of China. Nevertheless, Dengzhou was not simply a trading post in the Yuan dynasty. It was at the same time a military harbour supporting the Mongol invasions of the Japanese islands in I274 and I28 I during Kublai Khan's rule. As a result, Dengzhou gained a considerable military population. More men were stationed in the city to construct and refine war junks on a regular basis. The navy based in Dengzhou was also responsible for eradicating pirates, both Chinese and Japanese, who threatened the Bohai area. ${ }^{28}$

With the initiation of a sea ban on private coastal trade in the early Ming, the development of Dengzhou took a new turn. It significantly weakened the place of Dengzhou in the merchant networks of northeast Asia. However, restrictions on sea trade were not as effective as expected, ${ }^{29}$ so the Ming court restricted local engagement in merchant transport by establishing more coastal garrisons along the coast. Dengzhou's military apparatus was hence strengthened qualitatively and quantitatively, as recorded in the Account of Naval Exercise in Penglai (Penglai ge yue shuicao ji) written by $\mathrm{Xu} \mathrm{Ji},{ }^{30}$ Even though Dengzhou was not as prominent in maritime commerce in the early Ming as it had been before, it became a well-fortified military harbour in northern Shandong. ${ }^{31}$ The city was not the only seaport that experienced military enlargement, however. Almost the entire coastline of Shandong, including Yantai, Weihai, and Qingdao, similarly underwent coastal militarisation, with the aim of undermining pirates, smugglers, and unlicensed traders. ${ }^{32}$ Dengzhou only reemerged as a key port in the regional sea trade network of greater Bohai when this sea ban was abolished in I 567 and through the late Ming and early Qing dynasties most imports from Korea were shipped to China via Dengzhou. Dengzhou's growth is illustrated by the dramatic increase in the number of Korean merchants resident there between the early sixteenth and

\footnotetext{
${ }^{26}$ Dengzhou fuzhi, juan I3, 6b-7a.

${ }^{27}$ Dengzhou gugang shi bianwei hui, Dengzhou gugang shi (Beijing, I994), p. 96.

${ }^{28}$ Chi Jinguang, Sun Yanyan, "Dengzhou gang zai Zhongguo junshi shi shang de diwei," Shandong Dang'an, Vol. 5 (2008), pp. 66-67.

${ }^{29}$ Chao Zhongchen, Mingdai haijin yu haiwai maoyi (Beijing, 2005), pp. I32-138.

${ }^{30} \mathrm{Xu}$ Ji, Penglai ge yue shuicao ji.

${ }^{31}$ Liaoning sheng dang'an guan (ed.), Zhongguo Mingchao dang'an zonghui (Guilin, 200I), Vol. 7, pp. 452-475.

${ }^{32}$ Dong Jian, "Mingchao Dengzhou haifang jianshe gaishu," Journal of Nanchang College of Education, Vol. 27, no.5 (2012), p. I94.
} 
the mid-seventeenth centuries. ${ }^{33}$ Yet because the Ming court aimed to govern the coastal region in a precautionary manner, Dengzhou retained its military importance. As a result, the size of the garrisons in Shandong and Dengzhou grew substantially between the midand late- Ming. For example, in I 592, immediately following the first invasion of the Korean peninsula by the Japanese warlord Toyotomi Hideyoshi (I 536-I 598), the Wanli Emperor (r. I 572-I620) deployed 6,700 soldiers to the Jinan and Dengzhou garrisons. Dengzhou at that time had the duty to safeguard the maritime frontier from subsequent Japanese invasions and to provide necessary military support to other cities within the Bohai region (Bohai quyu). ${ }^{34}$ Until the seventeenth and the eighteenth century, Dengzhou continued to maintain its position as a military harbour. As the Korean emissary Yi Min-song recorded in I623 when he reached the Temple Island (Miaodao), just off the coast of Dengzhou, "I see fire signal stations established on each island peak, within sight of one another. Agricultural officers for the fields of the military settlements (tuntian nongmu) are everywhere. The war junks and merchant ships anchored along the coast are uncountable". ${ }^{35}$ Yi's account succinctly indicates a strong naval presence in Dengzhou. The city was evidently regarded as a strategic outpost within the context of Ming military coastal policies.

The above discussion, though admittedly brief, is sufficient to show that Dengzhou, despite its smaller size and population, was an important and strategic coastal city which inevitably played a major role in the maritime history of Northeast China. Dengzhou's continuous militarily and economic development from the Tang to the Ming, due to a set of geo-political factors, is also clear. Now it is essential to discuss in more detail the means and extent to which Dengzhou was maintained as a significant military harbour and coastal city within the high Qing maritime governing policies during the eighteenth century.

\section{Maritime Militarisation}

The political instability of the late Ming was apparent throughout the Shandong peninsula, and was accompanied by social and economic crises. In the I620s, the peninsula was ravaged by drought, famine, and misfortune, which gave rise to a host of internal rebellions affecting Dengzhou. According to an official stationed in Dengzhou in the I630s,

the city of Deng[zhou] abuts the seacoast where bandit evildoers always make their lairs. The land of the city is rocky, and no crops flourish or grow well. For these reasons, many people are poor. Since they are poor they are easily motivated to commit crime in order to fulfill their basic needs. The use of military force to ensure order is critical. ${ }^{36}$

In I63 I, the Ming commander Kong Youde (?-I652), leading his troops in mutiny, seized the city of Dengzhou and proceeded to establish an independent military regime on the Shandong peninsula. Although Kong's authority survived for only one year, the rebellion and the subsequent Ming government's campaign to suppress it severely devastated Dengzhou. As

\footnotetext{
${ }^{33}$ Yi Man-song, Gye he jo chen rok, in Im Ki-jung (ed.), Yonhaengnok chonjip (Seoul, 200I), Vol. I4, p. 3 I 5.

${ }^{34}$ Liaoning sheng dang'an guan (ed.), Zhongguo Mingchao dang'an zonghui, Vol. 7, p. 2 I I.

${ }^{35}$ Yi Man-song, Gye he jo chen rok, p. 335.

${ }^{36}$ Chen Zhongsheng, "Dengzhou fu xinjian chayuan ji," collected in the Daoguang chong xiu Penglai xian zhi (Nanjing, 2004), Vol. I2, p. 225.
} 
Chen Zhongshang, a newly appointed magistrate, described, "when I first looked out over all of Dengzhou I saw only bleak wasteland, overgrowth, collapsed walls, and broken roof tiles. I felt despair...... the sights and sounds of the animals, crops, tourists, and entertainers, once seen and heard throughout the area, will probably never be known again". ${ }^{37}$

As the famine in Shandong continued in the last few years of the Ming, starving refugees were dying on the roads around Dengzhou. Men and women committed suicide and the city slowly disintegrated. ${ }^{38}$ In February I636, eight years before Beijing fell to the Qing, the Manchus annexed the decaying Dengzhou. Yet Dengzhou did not revive as a flourishing sea port after the takeover. Seventeen years later, Dengzhou became the centre of a disturbance. In I66I, a peasant rebellion against the Qing led by Yu Qi, a native of Shandong, broke out in Shandong near Dengzhou. The rebellion escalated out of control along the Shandong littoral. Yu Qi and his followers captured Dengzhou and turned the city into a stronghold for their anti-Manchus campaign. The anti-Qing character of this added a new sense of political urgency to the threat of domestic crisis. This compelled the Qing court to develop new strategies to suppress rebellion as quickly as possible, and it took less than a year for the Qing to bring Dengzhou back into its fold. ${ }^{39}$ After Dengzhou was recaptured in I675, the pragmatic Emperor Kangxi began increasing the maritime militarisation of Dengzhou in order to strengthen the military capability of the Bohai region. The emperor ordered that additional soldiers be added to the Dengzhou naval base, which was first established by the Shunzhi Emperor in I644. The structure of the navy was also reorganised. Consisting of almost I 200 soldiers and 20 war junks and patrol boats, it was divided into two specific teams: the "front team (qianying)," and the "back team (houying)". The former was responsible for policing the sea space between Dengzhou and Ninghaizhou in the east, while the latter was ordered to police the sea space between Dengzhou and Laizhou in the west. In order to further expand the zone of policing, the qianying was relocated to Jiaozhou in I706 and renamed the Jiaozhou navy (Jiaozhou shuishi), whereas the houying continued to be stationed in Dengzhou. At that time, the sea in southern Shandong was patrolled by the Jiaozhou navy, while the sea surrounding northern Shandong, including a significant part of the Bohai Sea, remained under the control of the Dengzhou navy (the Dengzhou shuishi), which was considered large and solid. ${ }^{40}$ As an anonymous writer in the early Qing noted, compared to its structure in the Ming, the navy was effective in attacking seafaring targets (mainly pirates) across the waiyang sector, thereby preventing intruding vessels from entering the harbour. ${ }^{41}$ However, there was no consensus in the navy as to where intruders should be confronted. Some officials argued that the best way to deal with pirates was to stop them well away from the harbour, while others believed that pirates could be more effectively dealt with after they moved closer to the harbour because the waiyang sea was deep, vast and uncharted which made successful engagement with pirates difficult. They could easily turn away and elude

${ }^{37}$ Ibid.

${ }^{38}$ Wu Bosen (ed.), Ming shilu leizuan: Shandong shiliao juan (Wuhan, I994), p. 397.

${ }^{39}$ Dengzhou fuzhi, pp. I42-I 43 .

${ }^{40}$ Dengzhou fuzhi, pp. I $34-\mathrm{I} 35$.

${ }^{41}$ Taiwan sheng wenxian weiyuanhui (ed.), Qingchu haijiang tushou (Nantou, I996), p. I I. P.S. This anonymous writing is preserved at Academia Sinica in Taiwan. It was reprinted by the Taiwan sheng wenxian weiyuanhui and entitled as the Qing chu haijiang tushou in I996. 
authorities once they had sighted naval vessels. ${ }^{42}$ It was not until the Yongzheng period (1722-35) that clear instructions were given on the best strategies for the navy to follow. As Huang Yuanxiang, the general of Dengzhou, has suggested, war junks only attacked pirates after they were spotted entering the harbour area. ${ }^{43}$ One of the logics of Qing defensive, known as the "land-sea protection strategy (hailu lianfang)", promoted cooperation between imperial navy vessels and paotai (barbettes) to destroy pirates.

Maritime militarisation of Dengzhou underwent two waves of reform in I7I 4 and I734. In I7I4, the Kangxi emperor believed that "there was not much trouble on the sea" and the Bohai Gulf already could be effectively guarded by two other navies stationed in Fengtian and Tianjin. He then ordered the merging of the Dengzhou and Jiaozhou navies into one, called the Jiaozhou shuishi. The naval base in Dengzhou was thereafter moved to Jiaozhou, and the Jiaozhou shuishi became the only naval force to police the sea across northern and southern Shandong (nanbei fangqu). This relocation of the naval base to Jiaozhou diminished the military significance of Dengzhou. Altogether, for twenty years Jiaozhou functioned as the base to monitor all war junks operating in Shandong seas. ${ }^{44}$ This situation did not change until the Yongzheng emperor decided to re-elevate the maritime military structure in the Bohai region as well as the strategic importance of Dengzhou. Due to the gradual expansion of sea trade across the Bohai Gulf, the Yongzheng emperor implemented stronger military control to oversee domestic and overseas economic interactions there, especially interactions between the Shandong and Liaodong peninsulas. ${ }^{45}$ In fact, since Ming times, Shandong and Liaodong had long been considered two closely connected provinces. Tao Langxian, a governor of Shandong in the seventeenth century, once warned the imperial court that "Deng (Shandong) and Liao should not be governed separately". ${ }^{46}$ Situated at the northern tip of the Shandong province near the Liaodong peninsula, Dengzhou's location made it the preferred site to strengthen the ties between these two counties. As a consequence, in 1734 Yongzheng divided the Shandong navy into three divisions, with two divisions based in eastern Jiaozhou and the third based on "Mount Sheng (Shengshan)" at the eastern extremity of the Shandong peninsula. To ensure that the three divisions would fulfill their duties properly and collaboratively, the Yongzheng Emperor designated Dengzhou as the naval base to monitor and operate the three naval stations. This made the city a place where officials dealt with a wide range of logistical and administrative needs, such as personnel, revenues and expenses, shipbuilding administration, warehouses for weaponry, defense against intruders, training exercises, patrolling and seizing, military administration, and construction of barbettes, beacon-mounds, fortresses, as well as the levy system for law and order in ports and harbours. From then until the late eighteenth century, Dengzhou remained the centre of naval activity in Shandong. ${ }^{47}$

\footnotetext{
${ }^{42}$ For further discussion, see Ng Chin-keong, "Maritime Frontiers, Territorial Expansion and Hai-fang during the Late Ming and High Ch'ing”, in Sabine Dabringhaus and Roderich Ptak (eds.), China and Her Neighbours: Borders, Visions of the Other, Foreign Policy, 1oth to 19th Century (Wiesbaden, I997), pp. 224-23 I.

${ }^{43}$ Dengzhou fuzhi, pp. I34-I 35 .

${ }^{44}$ Ibid., p. I 42 .

${ }^{45}$ Ibid., p. I 34 .

${ }^{46}$ Tao Langxian's account is extracted from his Tao Yuanhui zhongcheng yiji, which is collected in Yu Hao (ed.), Ming Qing shiliao congshu (Beijing, 2005), pp. 72-87.

${ }^{47}$ Dengzhou fuzhi, p. I35.
} 
Dengzhou's strategic location continued to be highly valued in the mid-Yongzheng period. The Qing court established garrisons (wei) and military stations (suo) to guard the land and marine palisades. The wei-suo system along the coast was a pre-Manchu development that had existed in the Ming coastal defense system. The suo were subdivisions of the wei; and the wei and suo formed units of either battalions (qian hu suo) or companies (bai hu suo) that were actively involved in coastal defense. ${ }^{48}$ Under the wei-suo system, farmlands were provided to soldiers to promote self-sufficiency. Barbettes and beacon-mounds were constructed to protect the littoral as well as to send warning signals along the coast. In I 726, the first set of barbettes along the coast of the Shandong Peninsula was built by Emperor Yongzheng's officials in Dengzhou in "Guangdong style". ${ }^{49}$ From I 726 to I732, twenty coastal barbettes were constructed in what is today Longkou Harbour, Taozi Bay, Shuangdao Harbour, Chaoyang Harbour, Rongcheng Bay, Yangyuchi Bay, Shidao Bay, Jinghai Bay, Tadao Island, and Sushan Island. ${ }^{50}$ Until the middle of the eighteenth century, the Beijing government continued to provide financial support to these barbettes, which worked collaboratively with the Shandong navy to protect the Bohai region. All of this demonstrates the strategic importance of Shandong and Dengzhou in defending against pirates, domestic rebels, and other potential intruders from the sea.

Large-scale sea patrols (huaixiao), or "military tours", were launched annually in northern Shandong, most of which were monitored and operated by officials in Dengzhou. To get a complete picture of how the Qing court actualised its maritime militarisation across the Bohai Sea, the boundaries of the Shandong navy patrols under the supervision of the Dengzhou authority deserves analysis. The Dengzhou fuzhi recorded that the navy patrolled I,770 li of sea. ${ }^{51}$ The navy, which consisted of roughly 4 Io soldiers and 7 war junks, first departed from the Dengzhou naval base located in a harbour called "the bridge-mouth (Tianqiao kou). The navy then turned east and sailed all the way to the Mountain Sheng (Shengshan), the eastern limit of the maritime patrol. It then moved back to Dengzhou, passing the Temple Island, and continued to head west until reaching the mouth of the Daigu River (see Figure 6). During peacetime, large-scale sea patrols operated seven months a year, from March to September. This large-scale patrol cost the Qing court more than Io,ooo liang annually, according to records. Figures I, 2 and 3 depict the patrol limit of the Dengzhou navy and large body of water of the Bohai Gulf it covered. The seas off of Shangdong and Liaodong were divided by a vertical line cutting across Temple Island. Although the vertical line drawn in Figure I is not an actual dividing line drawn by the Qing government, according to the textual records in the Dengzhou gazetteer, we can assume that the islets located north of the Temple Island, namely the Gaoshan Island, Daqin Island, and Xiaoqin Island, were considered to be very far from Dengzhou. All of them were considered to be in the outer sea "waihai". Based on Dengzhou's naval capability, this island group was beyond its defense perimeter.

A coastal map entitled Shandong Dengzhou zhenbiao shuishi qianying beixun haikou daoyu $t u$ (hereafter daoyu $t u$; see Figure 7) also provides us with valuable information about the large-scale sea patrol operated by the Dengzhou navy. According to the description provided

\footnotetext{
${ }^{48} \mathrm{Gu}$ Yanwu, Tianxia junguo libing shu (Shanghai, I995), juan 26, I7b.

${ }^{49}$ Dengzhou gugang shi, pp. 91-92.

${ }^{50}$ Zhao Erxun (ed.), Qingshi gao (Beijing, I977), p. 4003.

${ }^{51}$ Dengzhou fuzhi, p. I 35 .
} 


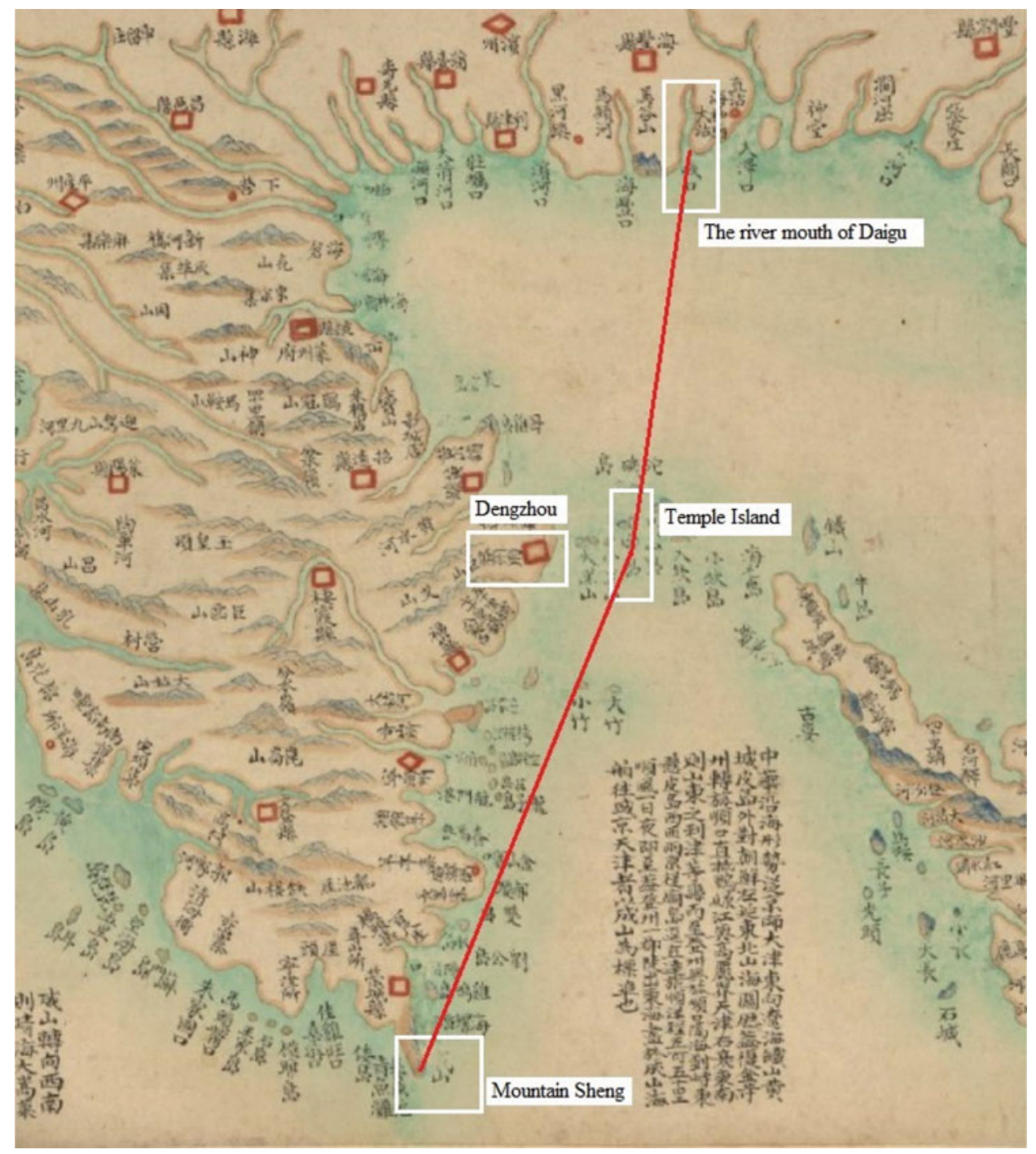

Figure 6. (Colour online) Patrol Limit of the Dengzhou Navy (Map: Qisheng yanhaitu; the I880s edition)

by the Chinese Academy of Science, where the daoyu $t u$ is now preserved, this coastal map was compiled under official supervision sometime between I 734 and I $842 .{ }^{52}$ It depicts the coastal situation of Dengzhou and portrays a series of significant islands off the Shandong coast. The marginalia on the coastal map indicate the time required for the Dengzhou navy to reach those islands. It also shows the patrol limit of the navy. For instance, it mentions that "from Dengzhou to the western part of Bohai the navy must pass by several islands. It p. 382 .

${ }^{52}$ Sun Jingguo (ed.), Yu tu zhi yao: Zhongguo kexue yuan tushuguan cang Zhongguo gu ditu xulu (Beijing, 20I2), 


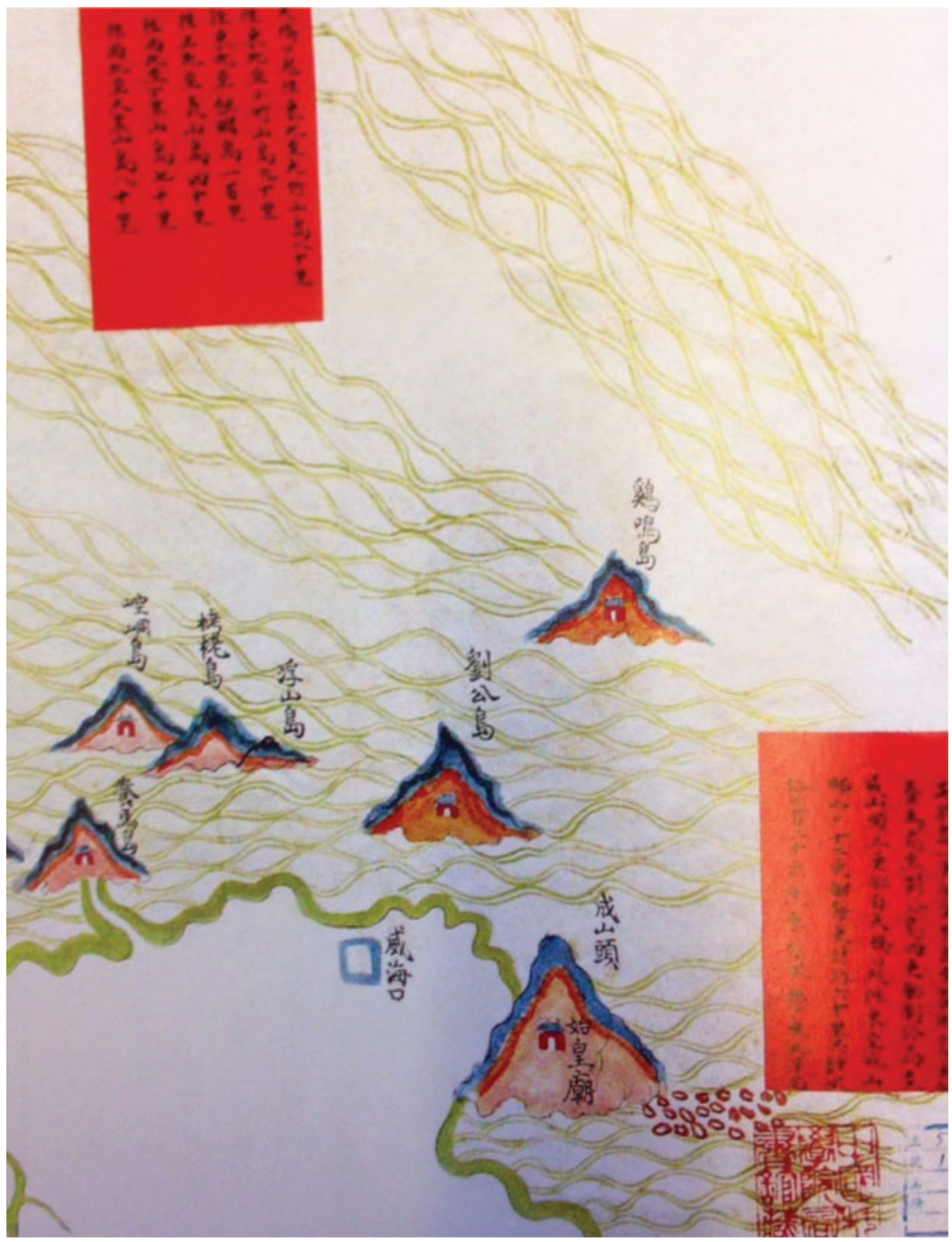

Figure 7. (Colour online) Shandong Dengzhou zhenbiao shuishi qianying beixun haikou daoyu tu

is a 720 li journey. The Daigu estuary marked the limit of the navy's partrol and acted as a dividing line between Shandong's water and Tianjin's water Once the navy reached the river mouth of Daigu, there would be the patrol limit and the dividing line between Shandong and Tianjin sea spaces".

The practice of sending vessels from Dengzhou to patrol the Bohai Gulf continued during the early Qianlong era. In collaboration with the land forces, Dengzhou authorities were able to assemble war junks in Shandong in order to police and protect the Bohai region. The navy was also effective in attacking their targets within their patrol limit, thus preventing any intruding vessels from entering the northern coast of Shandong Table I. By the late eighteenth century, patrol posts and forts equipped with weapons (from cannons to bows and arrows) dotted the coast. Most of the commanders in Dengzhou (Dengzhou zongbing) 
Table I. The eight different types of seawater (Shandong tongzhi [Yongzheng edition])

\begin{tabular}{|c|c|c|}
\hline $\begin{array}{l}\text { Types of } \\
\text { seascapes } \\
\text { (xunbie 汛別) }\end{array}$ & Descriptions & Strategic importance \\
\hline xian 險 & Seawaters between two isles & Obstruct enemies (宜用把截) \\
\hline yao 要 & $\begin{array}{l}\text { Seawaters where sailors found it most } \\
\text { favorable to pass through }\end{array}$ & Garrison (宜屯重兵) \\
\hline chong 沖 & Seawaters near the harbor or the coast & Defense (宜用防守) \\
\hline$h u i$ 會 & $\begin{array}{l}\text { Seawaters which connect all other type of } \\
\text { seascapes }\end{array}$ & $\begin{array}{l}\text { The best location to set up the } \\
\text { main camp for the commander } \\
\text { (宜立軍門) }\end{array}$ \\
\hline xian 閑 & The exit and entrance of currents & $\begin{array}{l}\text { The best location to construct forts } \\
\text { (宜設堡墩) }\end{array}$ \\
\hline san 散 & $\begin{array}{l}\text { Seawaters next to small isles, also suitable } \\
\text { to anchor for a short period of time }\end{array}$ & Police and patrol (宜用巡哨) \\
\hline$y u$ 迂 & $\begin{array}{l}\text { Seawaters where the direction of wind } \\
\text { changes }\end{array}$ & Observe enemies (宜用了望) \\
\hline$p i$ 僻 & Seawater connects to river & Scout (宜用偵探) \\
\hline
\end{tabular}

such as Shi Wenbing (?-I694), Huang Yuanji, and Dou Bin (I7I5-I802) were experienced and energetic in maintaining a competent navy. ${ }^{53}$ Therefore, there is little doubt but that the Dengzhou navy gradually became more sophisticated through development between the Kangxi and mid-Qianlong eras.

Dengzhou continued to serve as the military base monitoring the navies as well as assuming patrolling duties in Shandong. During the mid-Qianlong period (I742-I 783), however, Dengzhou naval structure contracted, due to a long period of peace and the prolonged absence of pirates and domestic rebels from the sea. From I742 to I783, the Qianlong Emperor reduced the number of soldiers and war junks supervised by the Dengzhou office and failed to provide sufficient repairs and refinements for the remaining vessels. ${ }^{54}$ As a consequence, personnel experienced low morale and were often afraid of going to sea. Troops were not properly trained and some warships were not suitably equipped. These problems were not rectified until the Daoguang period. As Tuohunbu, the governor-general of Dengzhou, and Yu Ming, the commander of Dengzhou, describe in a joint memorial:

In order to support the militarisation in Zhili and Fengtian, it is essential to increase the numbers of soldiers in Dengzhou. Dengzhou is important because it is a strategic city where we can oversee a large body of seawater attached to Shandong and Fengtian. The strategic location of Dengzhou enables us to control the seaway from Japan to Tianjin, as well as the sea routes from Fengtian to Zhili. It is where we can attack pirates and prevent foreigners from entering the northern part of our empire. At present, we only have I 87 soldiers stationed in Dengzhou, which is obviously insufficient to protect the country". ${ }^{55}$

\footnotetext{
${ }^{53}$ Dengzhou gugang shi, p. 92.

${ }^{54}$ Dengzhou fuzhi, p. I43.

${ }^{55}$ Qing shilu: Daoguang chao shilu, collected in DaQing lichao shilu (Taipei, I964), juan I 56.
} 
The above memorial indicates that Dengzhou's maritime military defenses were not developed after 1783 . From then until the early nineteenth century, no significant effort was made to expand or consolidate its naval structure. While not neglecting the importance of the Bohai Gulf, the Qianglong Emperor relied on the navies stationed in Daigu and Fengtian to police and patrol the Bohai Sea, rather than expanding or fortifying the Dengzhou navy itself. ${ }^{56}$ Compared Daigu and Fengtian, which developed larger naval bases, Dengzhou was no longer as advanced as in previous decades.

\section{Trade and Commerce}

In the eighteenth century, Dengzhou was a trading port as well as a naval base - although its military importance exceeded its economic importance. As of December I683, two months after Taiwan was annexed by the Qing Empire, Kangxi decided to lift the ban on Chinese navigation overseas by opening at least 50 large and small coastal ports to sea trade. ${ }^{57}$ Together with Tianjin in Zhili, Ningbo in Zhejiang, Yuntaishan in Jiangsu, Zhangzhou in Fujian, Dengzhou was one of the port cities in northeastern China that was opened to maritime trade, where merchants could conduct business and reside in the city. This is inscribed on a stone erected in the Penglai Pavilion: "Dengzhou (in the Kangxi-Yongzheng period) was the door for foreign merchants to trade with us and for Chinese merchants to trade abroad". Although a distinct customs office was never established in Dengzhou, the Dengzhou governor was assigned to regulate and supervise all manner of trading activities. Compared to newly opened sea ports in the south, which attracted large numbers of western and Southeast Asian traders, Dengzhou had a smaller volume of trade. This is largely because it was not profitable enough for western and Southeast Asian traders, coming mostly from the Strait of Malacca, to sail north if they could conduct their business in Canton. But this does not mean that Dengzhou lacked economic significance as a sea port in international trade at that time.

As briefly introduced in the previous section, Dengzhou had the good fortune of being located at the nexus of three important trade routes connecting Zhili, Liaodong, and Korea. The development of local commerce, ginseng trade, soybean paste production, and transportation during the eighteenth century contributed significantly to sustaining Dengzhou during this period and combined to revive its economy after the economic downturn of the late seventeenth century. Emperor Kangxi's lifting the sea ban promoted the development of coastal ports by legalising ocean shipping and permitting increased opportunities for maritime business. Kangxi's proclamations also served to strengthen government control of trade and produce tax revenues. Among the new regulations, laws that monitored and taxed the newly legalised sea trade were rigorously enforced. The emperor issued this imperial edict in I683,

"Without a regular means of collection, levying duties would trouble maritime traders, who would be subject to extortion from customs officials. Therefore, it is necessary to establish the

\footnotetext{
${ }^{56}$ Kun Gang, et. al., Qinding daQing huidian shili (Shanghai, I995), juan 547, p. 67.

${ }^{57}$ Gang Zhao, The Qing Opening to the Ocean, p. I I6.
} 
same system in coastal regions as in inland regions and appoint special officials to deal with related affairs". ${ }^{58}$

The Kangxi Emperor thus appointed two Manchu officials, Igeertu and Wushiba, as the first heads of the Guangdong (Guangzhou, Xiangshan, and Macau) and Fujian (Fuzhou, Nantai, and Xiamen) commissions, while two more customs offices were established in Zhejiang (Ningbo and Dinghai) and Jiangsu (Huating and Shanghai) over the subsequent three years. The establishment of the new customs structure suggests that the Qing was keenly aware that the trading patterns and dynamics of the maritime frontier were different from those of land and river regions.

Although Dengzhou was not one the four main customs bureaux opened in the Kangxi era, it was similar to the seaports where custom offices were located. The seafront was covered with warehouses encircled by storage yards. Surrounding them were competing companies established by Chinese managers and stock account intermediaries serving Korean and Japanese traders. As He Changling illustrated,

Since the sea ban was lifted by the Kangxi Emperor, the seaways were widely opened to traders. Maritime traders, who intended to reach Tianjin and Fengtian, began to pass by/ stop by Dengzhou. Thousands of trading vessels and businessmen help flourished the seawater of Dengzhou, in which you could hardly find this prosperity in the past (henggu weiyou). ${ }^{59}$

He Changling may be a bit exaggerated, but we are certain that the economy of Dengzhou was gradually reviving after the sea ban was lifted. Especially during the Qianlong period, when the eight trade routes were found along the coast, the seafront of Dengzhou was covered with warehouses encircled by storage yards. Surrounding them were companies established by Chinese managers and intermediaries serving Chinese from other provinces, and sometimes Korean, Manchu, and Japanese traders. ${ }^{60}$

The vessels anchored in Dengzhou were mostly sand junks (shachuan), which could carry up to I,500 shi (or 90 tons, one shi being approximately $60 \mathrm{~kg}$ ), medium-sized vessels with a capacity of 800 to $900 \mathrm{shi}$, and small boats with a capacity of only 400 to 500 shi. ${ }^{61}$ They carried fertilizer and soybeans from northern ports to Shanghai and took cotton textiles north. During the Yongzheng period, the sea route connecting Shandong and Shanghai was one of the most lucrative in north China sea trade. Zhang Zhongmin has estimated that, by the middle of the high Qing, the fertilizer trade alone amounted to more than two million taels annually. ${ }^{62}$ Yet, as discussed earlier, Dengzhou's gradual decline in economic importance during the Qianlong era, due to its diminished military importance, must be

\footnotetext{
${ }^{58}$ Cited from Jin Duanbiao, Liuhe zhen jilue, in Zhongguo xiangzhen zhi jichen (Nanjing, I992), juan 3, I4b. This passage is translated by Gang Zhao.

${ }^{59} \mathrm{He}$ Changling, Huangchao jingshi wenbian, juan 48, huzheng 23 , "caoyun xia."

${ }^{60}$ For further discussion, see Ye Ma, Huan Bo Hai jingji yanjiu (Beijing, date of publication needed here), and Xu Tan, "Qianlong Daoguang nianjian de Beiyang maoyi yu Shanghai de jueqi," Academy Monthly, vol. I I (20 I I), pp. I47-I54; Fan Jinmin, "Qingdai qianqi Fujian shangren de yanhai beicao maoyi," MinTai wenhua yanjiu, Vol. 34 (20I3), pp. 5-22; Zhang Haifeng, Qingdai Shandong Shangren beifang shandmao huodong de lishi dili yanjiu (Ocean Unviersity of China; Master Thesis, 2010).

${ }^{61}$ Ma Lin, "Yuan Ming Qing shiqi Shanghai shachuan hangyun ye de fazhan yu bianqian," Navigation, 20I4 no. I (March, 20I4), pp. 29-3I.

${ }^{62}$ Zhang Zhongmin, "Qing qianqi Shanghai gang fazhan yanbian xintan,” Zhongguo Jingjishi yanjiu, no. 3 (I987), pp. I70-I7I.
} 
kept in mind. Competing cities located in Northeast China, such as Tianjin, Jinzhou, Niuzhuang, and Jiaozhou, replaced it in importance. ${ }^{63}$ For example, due to its proximity to seaports in Southern China, Jiaozhou gradually became the major port of entry and departure for produce and coastal traffic in what is today the East China Sea region. ${ }^{64}$ By the late eighteenth century, Jiaozhou also received imports of such items as ginseng, bird nets, and seaweed from Korea and Japan. ${ }^{65}$ Dengzhou only regained its economic importance when the British required more port cities be opened for free trade in the I 858 Treaty of Tianjin. ${ }^{66}$

Throughout the eighteenth century, Dengzhou's merchants (Dengshang) had high social status, like those in other notable port cities. The Dengzhou merchants, who were usually labelled "Denglai businessmen," were active in important centres of trade along the coast of China. As the Dengzhou fuzhi and other provincial gazetteers record, "(Dengzhou merchants) are everywhere to pursue profits (min duo zhuli yu sifang)" ${ }^{67}$ Exploring both inland frontier regions and troubled waters, the maritime merchants from Dengzhou trade with peoples across the Bohai region as well as the southern part of China, such as Jiangsu and Zhejiang. ${ }^{68}$ One of the most enduring legacies of Dengzhou merchants is perhaps the design of the dongchuan or dengyou a merchant vessel specifically adapted to sail safely across the Bohai Sea. In a recent study of Dengzhou merchants, Tan Hongan suggests that the invention of the dengyou represents a highly advanced economic network created by the Dengzhou merchants in the Qing period. ${ }^{69}$ The development of this ship was thus a unique symbol of Dengzhou merchants as well as of Dengzhou city.

Yet the reputation of Dengzhou merchants failed to sustain the city's economic importance in the Bohai region in the late eighteenth century. The rise of other large port cities such as Tianjin and Lüshun overshadowed Dengzhou's position. ${ }^{70}$ The city was no longer as busy as before and most of the Dengzhou merchants moved their bases elsewhere. Those interested in Bohai sea trade preferred to set up their businesses in Tianjin, ${ }^{71}$ while those favouring trade with southeastern China relocated to Jiaozhou. The harbour of Dengzhou thus stopped growing and the number of trading vessels anchored near shore declined, ${ }^{72}$ whereas the city entered another wave of economic recession. Not until the I 820 s did the economic significance of the city slightly rise again. In I 825 , the Qing defined a new vision

\footnotetext{
${ }^{63}$ See Geng Sheng, Liu Fengming, Zhang Shoulu, Dengzhou yu haishang sichou zhilu (Beijing, 2009), "introduction."

${ }^{64}$ Hou Guoben, Jiaozhouwan gangkou gongneng (Beijing, I993), pp. 4-5.

${ }^{65}$ Nankai daxue Jiaozhou lishi wenhua yanjiu zhongxin, Jiaozhou lishi wenhua chutan (Tianjin, 2007).

${ }^{66}$ Tao Feiya, "Dengzhou chuanjiaoshi yu jindai Zhong Xi wenhua jiaoliu," Journal of Shandong University (Philosophy and Social Sciences), I992 no. 4, p. IоI.

${ }^{67}$ Dengzhou fuzhi, p. 73.

${ }^{68}$ For details, see Sun Yunzhi, "Dengzhou shangren," Yantai shifan xueyuan xue bao (zhexue shehui kexue ban), no. 3 (I989), pp. 68-75.

${ }^{69}$ Tan Hongan, "Jingshi haimen Dengzhou gang," Zhongguo jingying bao (25.08.2014). Online version: http://dianzibao.cb.com.cn/images/20I4-08/25/52/2074do4c.pdf

${ }^{70}$ Man Bun Kwan, The Salt Merchants of Tianjin: State-Making and Civil Society in Late Imperial China (Honolulu, 200I), pp. 27-28.

${ }^{71}$ Most of the Dengzhou merchants moved their bases to Tianjin due to the many functions Tianjian was enjoying at that time. By virtue of its location on the Grand Canal, the river system of the North China plain, and various overland routes, Tianjin served an economic maritime hub in North China and became a far more diversified commercial center in East Asia. I would argue that Dengzhou merchants were one of the groups who catalyzed the rapid urbanisation in Tianjin.

${ }^{72}$ Dengzhou gugang shi, p. 95.
} 
of a dual, collaborative approach to capital grain transport that relied on both transport by sea from Shanghai to Tianjin as well as on long-established imperial shipment on the Grand Canal. Dengzhou was one of the administrative offices along the sea route linking Shanghai and the northeast coast. In order to substantiate the managerial framework for grain transport on the sea route, the Qing officials sought to create an administrative infrastructure that enabled designated civil and military officials to respond directly to coastal security, navigational, and organisational difficulties. The organisers thus expanded the network of guard stations in Dengzhou and along the coast of Shandong. They also increased the number of navigational markers near Dengzhou to alert shipmen to navigational hazards. ${ }^{73}$ Due to the reinforcement of navigational and security operations, the economy of Dengzhou experienced its first wave of revival. The second wave of revival came later after the Second Opium War, when the British and the French forced the Qing court to open more treaty ports to accommodate the expanding trade in Asian markets and European interest extended beyond China's southeastern coast into the northeast-and specifically the Bohai zone. ${ }^{74}$ Following their investigation of the Shandong peninsula, the British chose Dengzhou because of its manageable size (as with their choice of Hong Kong) and its proximity to the capital. Like the treaty ports in Southeast China, Dengzhou was witness to the incursion of high imperialism in China in particular and East Asia in general. ${ }^{75}$ Along with Niuzhuang on the Liaodong peninsula, Dengzhou was one of the two treaty ports open to foreign traders in the Bohai zone. That extended transcultural interactions beyond the circle of trade with Korea and Japan to those of diverse and broad scope. The intercultural interactions that resulted from this are certainly worthy of investigation in future research. ${ }^{76}$

\section{Conclusion}

In his "On the Evolution of the Port City," Rhoads Murphey eloquently argued that port cities are different from other inland and hinterland cities in terms of their economic, social, political and cultural development. For Murphey, the difference between a port city and other type of cities is predominately determined by the function of a port city (the port function). Murphey defines "port function" as follows:

"The true port city by definition links very distant maritime spaces, and this is the reason for what is perhaps its most noticeable characteristic. Ports are inclusive, cosmopolitan, while the inland

\footnotetext{
${ }^{73}$ Jane Kate Leonard, “The Qing Strategic Highway on the Northeast Coast," p. 37.

${ }^{74}$ Alain Peyrefitte, Jon Rothschild (translation), The Immobile Empire (London, I989, reprinted in 20I3), p. 69.

${ }^{75}$ For Western imperialistic incursion in China, see Lydia H. Liu, The Clash of Empires: The Invention of China in Modern World Making (Cambridge, MA., 2006), pp. 70-I07 (Chapter 3: Figuring Sovereignty).

${ }^{76}$ In their recent edited volume Asia Inside Out: Connected Places, Eric Tagliacozzo, Helen F. Siu, and Peter C. Perdue have argued that "commerce in early modern empires, as well as nation states during colonial expansion, stimulated the circulation of material goods and migratory populations beyond regional or national boundaries. The institutions that profited from this commerce amassed great wealth, power, and ideological force but also provided unusual space for maneouver. The subsequent cultural fusion in regional arena has been well documented in material objects, moral geographies, language and cognitive maps, cultural intimacies, and in legal dilemmas. But the political ambiguities of these commercialised regions and the fluid cultural and political identities of those engaged with these places deserve more analysis". See their Asia Inside Out: Connected Places (Cambridge, MA., 20I5), pp. 6-7. Situating in such framework, the cultural and economic interactions between East and West found in nineteenth century Dengzhou could certainly help us expand the dynamics of the city itself as well as the greater Bohai region in the early modern period.
} 
is much less varied, much more exclusive, single faceted rather than diverse... Port functions, more than anything else, make a city cosmopolitan... A port city is open to the world, or at least to a varied section of it. In it races, cultures, and ideas as well as goods from a variety of places jostle, mix, and enrich each other and the life of the city. The smell of the sea and the harbor, still to be found ... in all of them, like the sound of boat whistles or the moving tides, is a symbol of their multiple links with a wider world, samples of which are present in microcosm within their own urban areas". ${ }^{77}$

By the end of the late eighteenth century, Dengzhou was considered to be "cosmopolitan," open to the wider world, especially to the Northeast Asian market thronged with Chinese (from the north and the south), Korean, Japanese, Manchu, and sometimes Russian traders. Situated at the nexus of three important trade routes connecting Shandong, Zhili, Liaodong, and Korea, the seaborne economy of Dengzhou was deliberately monitored and supervised by the government. The development of ginseng trade, local commerce, and transportation contributed significantly to Dengzhou's importance. Hundreds of ocean craft plowed the port of Denghou as their sails billowed in the winds that tied together transcultural interactions in Northeast Asia. Yet the dramatic rise of Tianjin and Jiaozhou in the late Qianlong era overshadowed the economic significance of Dengzhou, quickly displacing it as trading hubs of northeast Asia. Only after the British declared their interest in urbanising Dengzhou in the mid-nineteenth century was economic development in the city revived.

However, it must be noted that the "port function" of Dengzhou differed from other inland Chinese cities, not only in terms of trade and commerce, but in its unique military development - particularly in relation to port cities on China's southeastern coast. On one hand, the geographical location of Dengzhou made it a natural port of call for travellers in Northeast Asia; on the other, its strategic location made it a magnet for the Qing administration to set up a naval base to protect the imperial region. As we have seen in this paper, the Qing court in the eighteenth century did not ignore the significance of Dengzhou as well as the Bohai Sea. By deploying vessels and sailors within the Dengzhou seawater, the government considered Dengzhou a strategic center to oversee the Bohai region, connecting three coastal provinces in northeastern China. In order to govern this piece of maritime territory thoroughly and deliberately, the Dengzhou navy was responsible for policing the region on a regular basis as well as monitoring and regulating all other naval stations. The maritime militarisation project prior to the middle of the Qianlong period integrated Dengzhou into a military network connecting Zhili, Liaodong, and Shandong, the three provinces most significantly underlying Manchu government rule. Yet the military development of Dengzhou cannot be seen in isolation from its immediate environment. Dengzhou's military importance gradually weakened during a long period of peace across the Bohai Sea. The Qianlong emperor thus reduced the number of soldiers guarding the Dengzhou naval base and came to rely more on the Daigu and the Fengtian navies to police the Bohai zone. As a consequence, Dengzhou' maritime militarisation in the late eighteenth century regressed from what it had been decades before.

\footnotetext{
${ }^{77}$ Rhoads Murphey, "On the Evolution of the Port City," in Frank Broeze (ed.), Brides of the Sea: Port Cities of Asia from the 16th-20th Centuries (Honolulu, I989), p. 225.
} 
In studying the connection between China and the sea in the eighteenth century, western historiography has long focused on port cities in southeast China. The scale of shipping along the northeastern coast was smaller than that along the southeastern coast because most of the East-West transactions took place in large coastal cities such as Canton, Amoy, and Fuzhou. Yet, to fully evaluate maritime policy during the high Qing and comprehend the coastal history of China, it is not enough to merely inquire into the significance of the southeastern region; the northeastern region, and the Bohai zone in particular, can hardly be ignored. Dengzhou is but one of the cities in that zone that deserves attention. The histories of Yingkou, Weihai, and Qinhuangdao, for instance, are equally worthy of investigation, especially now when the PRC government is earnestly developing the Bohai Seaway Strategic Project (BSSP; Huan Bohai jingji quan zhanglüe jihua). In order to get a relatively thorough picture of the history of Chinese port cities and China's connection to the sea, I would like to take this opportunity, once again, to invite potential researchers to move northward in their research and not to confine themselves to the "Southeast Chinacentric" framework in studying the maritime history of late imperial China. I believe this is a constructive way to gain a better understanding of the history of coastal China as well as a comprehensive picture of maritime Asia in the early modern period.

We should also try to go beyond the Asian setting by comparing port cities in Northeast China with those in the West. Although the two were certainly not identical in terms of political functions and economic significance, their "port functions" may have more in common than is recognised. The study of Dengzhou as both a military and commercial port city reminds me of the chronicles of Sevastopol, a port city in Russia surrounded by the Black Sea. Both a naval base and a commercial port city in Russia, Sevastopol experienced serious ups and downs over the eighteenth century. Much the same occurred in Dengzhou at about the same time, following Emperor Qianlong's decision to reduce the number of soldiers in the Dengzhou navy, which then led to the economic decline of the city. Such comparison may therefore serve as a window into the global history of urbanization of port cities in the pre-industrial era. By investigating these cases, we can understand how port cities experienced unique and similar patterns of urban development within different political, cultural, and economic contexts. This might also help trace the origin of "cosmopolitan features" that exist in the port cities of today's globally connected economy. <C.Y.Po@1se.ac.uk>

\section{Chronicle of Dengzhou (I644-I840)}

I644 (Shunzhi yuan nian) Establishment of the Dengzhou naval base.

I648 (Shunzhi 5 nian) Outbreak of the Yu Qi 于七 rebellion, soon supressed by the Qing court.

I653 (Shunzhi Io nian) The promulgation of the Liaodong zhaomin kaiken jiangli tiaoli 遼東招 民開墾獎勵條例. A substantial number of migrants from Dengzhou migrated to the Liaodong peninsula.

I654 (Shunzhi I n nian) Some anti-Qing rebels were captured by the Qing in Dengzhou on their way to Chosŏn Korea.

I659 (Shunzhi I6 nian) The Dengzhou minister Xu Kexian 許克先 began constructing the Dengzhou water castle (shuicheng 水城). 
I66I (Shunzhi I8 nian)

I663 (Kangxi 2 nian)

I666 (Kangxi 5 nian)

I68 I (Kangxi 20 nian)

I684 (Kangxi 23 nian)

I698 (Kangxi 37 nian)

I703 (Kangxi 42 nian)

I704 (Kangxi 43 nian)

I706 (Kangxi 45 nian)

I7I4 (Kangxi 53 nian)

I7I5 (Kangxi 54 nian)

I729 (Yongzheng 7 nian)

I734 (Yongzheng I2 nian)

I762 (Qianlong 27 nian)

I777 (Qianlong 42 nian)

I783 (Qianlong 48 nian)

I792 (Qianlong 57 nian)

I 80 I (Jiaqing 6 nian)

I 803 (Jiaqing 8 nian)

I 8 I I (Jiaqing I6 nian)

I 8 I 2 (Jiaqing I 7 nian)

I 8 I6 (Jiaqing 2 I nian)
Expansion of the Dengzhou navy in numbers of soldiers and battleships [the exact number is unknown].

All islanders settling off the Shandong coast were forced to move back to the coast.

The Dengzhou and Laizhou patrolling zones (haifang dao 海防道) were combined into one patrolling zone named Deng-Lai dao 登萊 道.

The sea blockade policy was abolished.

He Changling 賀長齡 recorded that "Since the sea ban was lifted by the Kangxi Emperor, the seaways were widely opened to traders. Maritime traders, who intended to reach Tianjin and Fengtian, began to stop by Dengzhou."

A large scale famine occurred in Chosŏn. The Qing helped relieve the famine by shipping food and suppliers from Dengzhou.

Qingzhou was integrated into the Deng-Lai dao, and the Denglai dao was renamed the Deng-Lai-Qing dao 登萊青道. The maritime defense of these three places were merged into one coherent system.

The number of soldiers in the Dengzhou navy was increased by $\mathrm{I} 200$. The navy was divided into two specific teams: the "front team (qianying 前營)," and the "back team (houying 後營)."

In order to further expand the zone of policing, the qianying was relocated to Jiaozhou and renamed the Jiaozhou navy (Jiaozhou shuishi), whereas the houying continued to be stationed in

Dengzhou. The qianying and houying navies were called the Shandong navy.

The number of soldiers in the houying navy was reduced by 700 , and Io vessels from Dengzhou were deployed to Lüshun.

Chen Shangyong 陳尚勇, the leader of an anti-Qing rebel force, led 3000 war junks (bird boat) intending to capture Dengzhou but was quickly supressed by the Shandong navy.

The number of soldiers in the Shandong navy was increased [the number is unclear].

The Shandong navy was divided into three divisions, with two divisions based in eastern Jiaozhou and the third based on "Mount Sheng (Chengshan 成山)" at the eastern extremity of the Shandong peninsula. Dengzhou was the naval base to monitor and operate the three naval stations.

$\mathrm{Xu} \mathrm{Ji}$ 徐績 was assigned to investigate the Dengzhou water castle. His report was entitled the Penglai ge yue shuicao ji 蓬萊閣閱水操記.

In order to maintain the safety of the Bohai Sea and resolve the problem of unlicensed merchant ships anchoring in Shandong, every kind of vessel entering the Dengzhou harbor had to go through a new inspection procedure.

The emperor reduced the number of soldiers and war junks supervised by the Dengzhou office.

A severe famine occurred in Shandong, Dengzhou was one of the affected cities.

Another famine occurred, generating starving refugees everywhere in Dengzhou.

People from Dengzhou were prohibited from migrating to Liaodong via the Bohai Sea.

Large scale drought occurred in Dengzhou, along with another wave of economic depression.

People from Dengzhou were once again prohibited from sailing across the Bohai Sea and migrating to Liaodong.

The naval structure of Dengzhou was strengthened. Two battleships from Gangzhou were relocated to Dengzhou. 
I 8 I 8 (Jiaqing 23 nian)

I 8 I9 (Jiaqing 24 nian)

I 825 (Daoguang 5 nian)

I83 I (Daoguang I I nian)

I832 (Daoguang I2 nian)

I840 (Daoguang 20 nian)
Extra fog guns (wupao 霧炮) were constructed in Temple Island.

Reconstruction of the Penglai water castle began.

Dengzhou was selected as a checkpoint to oversee the official sea lane connecting north and south China (the sea lane for grain transport), which was recently inaugurated by the Qing court.

The soldiers guarding the Dengzhou water castle were increased by roughly iooo.

A British vessel surveyed the topography and seawaters surrounding the Dengzhou harbor.

Outbreak of the First Opium War. More than 30 British battleships entered Dengzhou seawater by force.

\section{Glossary}

bai hu suo 百户所

Bohai quyu 渤海區域

Bohai 渤海

Chen Zhongshang 陳忠尚

Dengshang 登商

dengyou 登郵

Dengzhou fuzhi 登州府志

Dengzhou shuishi 登州水師

Dengzhou 登州

diji minpin 地癐民貧

dongchuan 東船

Dou Bin 竇璸

Dushi fangyu jiyao 讀史方輿紀要

fenjie 分界

$\mathrm{Gu}$ Zuyu 顧祖禹

Haifang zonglun 海防總論

hailu lianfang 海陸聯防

henggu weiyou 恆古未有

houying 後營

huaixiao 會哨

Huan Bohai jingji quan zhanglüe jihua 環渤

海經濟圈戰略計劃

Huang Yuanji 黃元濟

Jiang Chenying 姜宸英

Jiaozhou shuishi 膠州水師

jingji 京畿

Kong Youde 孔有德
Laizhou 萊州

Miaodao 廟島

min duo zhuli yu sifang 民多逐利於四方

nanbei fangqu 南北防區

Ninghaizhou 寧海洲

Niuzhuang 牛莊

paotai 炮台

Penglai ge yue shuicao ji 蓬萊閣閱水操記

qian hu suo 千户所

qianying 前營

Qingzhou 青州

Quanzhou 泉州

Shachuan 沙船

Shandong Dengzhou zhenbiao shuishi qianying beixun haikou daoyu tu 山東登州鎮標水師 前營北汛海口島嶼圖

Shengshan 成山

taixi 泰西

Tianqiao kou 天橋

tuntian nongmu 屯田農務

waiyang 外洋

weisuo 衛所

Yu Qi 于七

Yuntaishan 雲台山

Zhangzhou 漳州

zongbing 總兵

Ronald C. Po 